Z Badań nad Książką i Księgozbiorami Historycznymi 2019. T. specjalny: Dla Niepodległej The Studies into the History of the Book and Book Collections 2019. Special issue: For an Independent Poland

ISSN 1897-0788, e-ISSN 2544-8730

www.bookhistory.uw.edu.pl

Paweł Redlarski

https://doi.org/10.33077/uw.25448730.zbkh.2020.192

Miejska Biblioteka Publiczna w Tucholi im. Aleksandra Janty-Połczyńskiego,

Tuchola, Polska

pawel.redlarski@wp.pl

\title{
Kształtowanie tożsamości polskiej w okresie zaborów oraz umacnianie świadomości narodowej w czasach II Rzeczypospolitej na przykładzie Towarzystwa Czytelni Ludowych w powiecie tucholskim
}

\begin{abstract}
Formation of Polish Identity during the Partitions and Strengthening National Consciousness in the Second Polish Republic on the example of the People's Reading Society in the Tuchola District

The Society of People's Readings established in 1880 had a great influence on shaping the national consciousness of Poles living under the occupation. The main aim of the society was to be realized through the creation of a library network in the areas of the Prussian partition. People who lead the library of the Society of People's Readings should not only share books, but above all, broaden the horizons of people from the lower social layer. That is why popular science meetings, reading meetings, evening parties and folk rallies were organized. In the Tuchola County in 1914 there were 12 libraries with 728 books in their collections. In 1921, the Tuchola district committee, consisting of 14 libraries, was one of the most energetic in the Pomeranian Voivodship.

Key words: The Society of People's Readings - library - Tuchola, County - Tuchola - Prussian partition - National consciousness.

Słowa kluczowe: Towarzystwo Czytelni Ludowych - biblioteka - powiat tucholski - Tuchola, zabór pruski - świadomość narodowa.

„Z Badań nad Książką i Księgozbiorami Historycznymi” - Udział zagranicznych recenzentów w ocenie publikacji; Stworzenie anglojęzycznej wersji wydawniczej publikacji; Digitalizacja tomów archiwalnych rocznika w celu zapewnienia otwartego dostępu do nich przez Internet oraz wdrożenie i utrzymanie cyfrowej platformy redakcyjnej - zadanie finansowane w ramach umowy $\mathrm{nr}$ 653/P-DUN/2019 ze środków Ministra Nauki i Szkolnictwa Wyższego przeznaczonych na działalność upowszechniającą naukę.
\end{abstract}


We wrześniu 1772 r. władze Rzeczypospolitej zostały poinformowane o traktatach rozbiorowych podpisanych pomiędzy Austrią, Prusami i Rosją. Podział Rzeczypospolitej stał się faktem. Pomorze, włączone do państwa pruskiego, najdłużej ze wszystkich polskich ziem znajdowało się pod obcym panowaniem. Musiało minąć prawie półtora wieku, aż kolejne pokolenie Polaków doczekało się niepodległości. W tym czasie na Pomorzu Nadwiślańskim dokonały się ważne przeobrażenia społeczne, które swoje źródła miały w procesach charakterystycznych dla regionów pogranicza. Od średniowiecza na tej przestrzeni „stykały się różne kultury, mieszały obyczaje i języki, współistniały odmienne wyznania"'.

Pomorskie rody ziemiańskie kultywowały dawne staropolskie tradycje i podkreślały swoje przywiązanie do polskiej kultury, chociaż niemczyzna nie stanowiła dla nich elementu obcego i wrogiego. Jednakże przedstawiciele tej warstwy społecznej, chcąc odnieść sukces zawodowy, musieli zaakceptować nowe warunki społeczno-polityczne i przyjąć język oraz obyczaje zaborcy. Wyróżnikiem świadczącym o przynależności narodowej było wyznanie - rzymsko-katolickie ${ }^{2}$. W latach 30. i 40. XIX w. zaczęła konkretyzować się świadomość narodowa Polaków zamieszkujących ten obszar. Działania germanizacyjne skierowane przeciwko językowi polskiemu oraz kościołowi katolickiemu zaczęły wzbudzać niechęć. Przełomowy dla ukształtowania się świadomości narodowej Polaków okazał się rok 1848. Wiosna Ludów i uruchomione przez nią procesy - rozwój wolnej prasy, aktywność polityczna, oddolne zrzeszanie się obywateli - przyniosła nadzieję na odzyskanie niepodległości ${ }^{3}$. W $1848 \mathrm{r}$. w Berlinie powstało stowarzyszenie o nazwie Liga Narodowa Polska. Miała ona na celu skupić „,w jedno ognisko sił moralnych i materialnych, tak w kraju jak i zagranicą do jawnego i legalnego działania na korzyść narodowości polskiej”4. Jednym z celów szczegółowych Ligi było „rozwijanie oświaty narodowej przez książki, szkoły, ochrony itd."”. Podczas zgromadzenia Ligi Polskiej na Prusy Zachodnie w Chełmnie gorliwy działacz narodowy - Ignacy Łyskowski - zaapelował, aby zakładano biblioteczki parafialne. Jedyną przeszkodą była cena książek, dlatego zaproponował, aby każda Liga powiatowa przeznaczyła pewną kwotę na ten cel. Zebrane w ten sposób pieniądze miały pokryć dodruk książek, a zarazem obniżyć koszty całego przedsięwzięcia. Dzięki temu w każdej bibliotece parafialnej mogłyby

1 T. Krzemiński, Codzienność mniejszych miast Pomorza Nadwiślańskiego końca XIX i pierwszych dziesięcioleci XX wieku. Zmiany warunków materialnych i przeobrażenia obyczajowości, Warszawa 2017, s. 10.

2 Tamże, s. 22.

Tamże, 23-24.

4 W. Jakóbczyk, Cieszkowski i Liga Polska, „Przegląd Historyczny” 1948, t. 38, s. 142.

5 Tamże, s. 152. 
znaleźć się „książeczki [...] pisane dla ludu”. Ksiądz Alfons Mańkowski podkreślił w swym artykule, że dzięki inicjatywie I. Łyskowskiego na Pomorzu zapoczątkowana została „działalność oświatowa za pomocą bibliotek”7. Czytelnictwo polskich książek miało przyczynić się do wzrostu wykształcenia oraz świadomości narodowej wśród Polaków, a zarazem stać się jednym z elementów przeciwstawiania się germanizacji. Warto w tym miejscu zaznaczyć, że w 1850 r. biblioteka w okręgu chojnickim ${ }^{8}$ Ligi Polskiej posiadała w swych zbiorach 150 woluminów9 . Biorąc pod uwagę krótki okres działalności oraz ówczesne możliwości wydaje się, że zgromadzono dość pokaźny księgozbiór.

Niestety po dwóch latach władze pruskie rozwiązały Ligę. Jednak niepowodzenia nie zraziły I. Łyskowskiego. W 1869 r. powołał do życia Towarzystwo Moralnych Interesów, które miało pobudzać uczucia patriotyczne i krzewić oświatę. Sprostać temu miały kółka rolnicze i czytelnie zakładane we wsiach oraz biblioteki przy kościołach parafialnych. Olbrzymią zasługą Łyskowskiego było pozyskanie do współpracy właścicieli ziemskich, którzy dzięki posiadanym funduszom mogli wspierać działalność towarzystwa. W krótkim czasie Towarzystwo Moralnych Interesów „w Prusach Zachodnich wydało błogie owoce na specyalnem polu oświaty ludu i czytelnictwa" ${ }^{10}$.

Wielkim orędownikiem oświaty ludowej w regionie był Józef Janta-Połczyński -ziemianin z Wysokiej k. Raciąża. W 1849 r. został członkiem Ligi Polskiej, a po jej likwidacji jednym z „,najgorliwszych i najofiarniejszych zwolenników" Towarzystwa Moralnych Interesów założonego w 1869 r. w Toruniu. Ziemianin z Wysokiej był wielkim filantropem

przez kilkanaście lat wydawał rocznie 200 talarów i więcej na zakup książek. Rozdawał je na wszystkie strony, chętni i ciekawi sami się po nie do niego zgłaszali, wysyłał rodakom na obczyznę nawet do Ameryki Półn. i Brazylji [...] liczba rozdanych i rozesłanych przez niego książek wynosiła coś $10.000^{11}$.

Z jego inicjatywy utworzono ok. 40 bibliotek parafialnych. Poprzez swoją działalność na Pomorzu był postrzegany jako wielki patriota, który pomimo swego majątku prowadził bardzo skromne życie ${ }^{12}$.

6 A. Mańkowski, Czytelnictwo i bibliotekarstwo polskie na Pomorzu 1849-1889, „Mestwin” 1930, nr 15, s. 1.

7 Tamże, s. 2.

8 Powiat tucholski został utworzony w 1875 r., wcześniej Tuchola i okolice należały do powiatu chojnickiego

9 J. Szwankowski, Tuchola w latach 1815-1920, [w:] Tuchola. Od pradziejów do wspótczesności. Praca zbiorowa, pod red. W. Jastrzębskiego, J. Szwankowskiego, Bydgoszcz-Tuchola 2010, s. 321.

10 Tamże, s. 4.

11 A. Mańkowski, dz. cyt., s. 4.

12 Ś.p. Józef Janta-Połczyński, „Dziennik Poznański” 1890, nr 27, s. [4]; J. Palędzki, Ś.p. Józef Janta-Połczyński, „Gazeta Toruńska” 1890, nr 23, s. 2-3; Pogrzeb ś.p. Józefa Połczyńskiego, „Gazeta 
Biblioteki i czytelnie stały się nie tylko ośrodkami, które uświadamiały najmniej wykształcone warstwy społeczeństwa, ale także integrowały lokalne społeczności. Jan Kałdowski, który w 1863 r. założył pierwszą czytelnię w Śliwicach, w jednym z artykułów opublikowanych w „Przyjacielu Ludu” tak określił miejsce, w którym ona powstała: „strony nasze ubogie, a lud ciemny”"13. Słabe wykształcenie okolicznych mieszkańców nie było przeszkodą. W każdą niedzielę w mieszkaniu Jana Lipkowskiego urządzano spotkania, na których czytano książki i polską prasę. Na pierwsze spotkanie inaugurujące działalność czytelni przyszło 27 osób, po kilku miesiącach liczba ta wzrosła ponad trzykrotnie ${ }^{14}$. Prowadzenie śliwickiej czytelni w kolejnych latach przejęło Towarzystwo Rolnicze, ale stan czytelnictwa nie był zadowalający ${ }^{15}$. Dopiero w 1877 r. dzięki staraniom wikarego parafii św. Katarzyny - księdza Teofila Krzeszewskiego powołano „Czytelnię ludową dla parafii Śliwickiej i okolicy”, której celem było „czytanie pożytecznych i dobrych książek i czasopism -

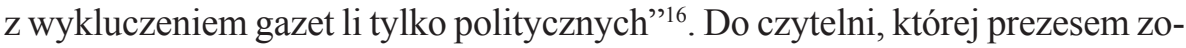
stał proboszcz ks. Marcin Kiljahn, zapisało się 100 osób. Na początku stycznia 1878 r. z czytelni posiadającej 238 książek korzystało 158 osób. Data założenia śliwickiej czytelni sugeruje, że mogła ona powstać z inicjatywy Towarzystwa Oświaty Ludowej założonego w 1872 r. w Poznaniu. W założeniu miało ono szerzyć oświatę wśród ludu, aby mało uświadomieni Polacy mogli przeciwstawić się germanizacji. Jednak dzięki zakładanym bibliotekom, w których udostępniane były polskie wydawnictwa przede wszystkim miała wzrastać świadomość narodowa. Niestety po sześciu latach działalności Towarzystwo Oświaty Ludowej otrzymało zakaz działalności, gdyż aktywnie włączyło się w obronę wiary i polskiej narodowości, a był to okres nasilonej walki państwa pruskiego z kościołem katolickim - kulturkampfu. Wraz z likwidacją TOL władze pruskie dążyły do zamknięcia śliwickiej czytelni i ukarania jej twórców. Dnia 20 X 1789 r. tucholski sąd skazał głównych działaczy śliwickiej czytelni na grzywnę i areszt za przyjmowanie do towarzystwa kobiet i dzieci ${ }^{17}$.

Najdłużej działającą polską organizacją oświatową było Towarzystwo Czytelni Ludowych w Poznaniu, które powstało 11 XI 1880 r. Na przestrzeni prawie 60 lat działalności najbardziej przyczyniło się do rozwoju czytelnictwa i bibliotekarstwa, za główny cel postawiło sobie ,szerzenie pożytecznych, religijne uczucia ludu podnoszących i pouczających książek polskich, oraz

\footnotetext{
Toruńska" 1890, nr 25, s. 4.

13 Cyt. za A. Węsierski, Dzieje parafii św. Katarzyny w Śliwicach w czasach zaboru pruskiego (1870-1920), Śliwice 2009, s. 65.

14 Tamże, s. 66.

15 Tamże, s. 67.

16 Tamże, s. 70.

17 Tamże.
} 
zakładanie (bezpłatnych) bibljotek ludowych"18. W swej działalności czerpało z kilkudziesięcioletnich doświadczeń polskich organizacji oświatowych. TCL powołane z inicjatywy Franciszka Dobrowolskiego - redaktora „Dziennika Poznańskiego" oraz Mieczysława Łyskowskiego i Władysława Niegolewskiego swoje cele musiało zredagować w statucie tak, aby władza pruska nie mogła go rozwiązać za działanie niezgodne z ustawą o języku urzędowym ${ }^{19}$.

Poprzez udostępnianie książek działacze tej organizacji chcieli przeciwstawić się polityce zaborcy pruskiego walczącego z językiem polskim. Powstające biblioteki i ich działalność oświatowa wśród najniższych warstw społeczeństwa stały się jednym z elementów w walce z zaborcą. Józef Kisielewski w swym artykule zauważył, że „w działaniu biblioteki można zawsze dopatrywać się cech walki - walki z brakiem uświadomienia - to w polskich warunkach charakter ten wyrósł ponad zwykłą miarę [...] dlatego, że cena przyszłego zwycięstwa stanowiła daleko wyższą wartość, niż w warunkach normalnych" ${ }^{20}$. W pierwszym roku istnienia TCL założyło 150 bibliotek ludowych, ale jak zaznaczył ksiądz Arkadiusz Lisiecki ,pierwsze lata istnienia towarzystwa to nieustanna walka z przeciwnikiem, to zaciekła obrona każdej prawie polskiej książki, każdej myśli narodowej, to nieustanne rewizje, przesłuchy, procesy, skargi" ${ }^{21}$. Władze pruskie wiedziały, że ci, co czytają polskie książki, mogą stać się propagatorami polskiej myśli narodowej oraz jawnie sprzeciwiać się polityce germanizacyjnej. Rozwój polskiego bibliotekarstwa na terenach zaboru pruskiego był wiec postrzegany, jako ogromne zagrożenie ${ }^{22}$. Od 1884 r. wzrosła liczba wyroków sądowych dla bibliotekarzy za upowszechnianie „niebezpiecznych” dla państwa pruskiego książek ${ }^{23}$.

Dlatego działania cenzury były prowadzone na szeroką skalę, nie ominęły również powiatu tucholskiego. W imieniu władz pruskich podejmował je komisarz ministerialny Henryk Rex, który recenzował „podejrzane” polskie książki, a niekiedy osobiście przeprowadzał rewizje bibliotek. W 1889 r. skonfiskowano i wysłano do „obiektywnej” recenzji 14 książek z biblioteki ludowej w Śliwicach. Wśród nich były: nowela Henryka Sienkiewicza Za chlebem wydana w 1880 r.; Historia o ucisku kościoła grecko-katolickiego przez Moskali w diecezji chetmińskiej Piotra Zbrożka, która została wydrukowana w 1874 r.;

18 Cyt. za J. Kisielewski, Bibliotekarstwo powszechne na zachodnich ziemiach Polski. Z okazji 50-lecia pracy Towarzystwa Czytelni Ludowych 1880-1930, „Przegląd Biblioteczny” 1930, z. 3, s. 287.

1955 lat pracy T.C.L. dla Polski 1880-1935. Rzut oka na historię Towarzystwa Czytelni Ludowych, Poznań 1935, s. 4-5.

20 J. Kisielewski, Bibliotekarstwo powszechne..., s. 282.

21 A. Lisiecki, Czterdziestolecie T.C.L., „Przegląd Oświatowy” grudzień 1921, s. 85-89.

22 J. Wróblewski, Polskie biblioteki ludowe w zaborze pruskim i na terenie Rzeszy Niemieckiej w latach 1843-1939, Olsztyn 1975, s. 71.

2355 lat pracy T.C.L. dla Polski..., s. 5. 
opracowanie Józefa Chociszewskiego Jan III Sobieski, król Polski i obrońca chrześcijaństwa; dwutomowy Pamiętnik oblężenia Częstochowy 1655 r. Augustyna Kordeckiego oraz książki: Jasna Góra Częstochowska; Obrazki historyczne; Pamiętna noc listopadowa; Dwaj sasiedzi; Żywoty świętych Patronów narodu Polskiego J. Chociszewskiego. Wymienione pozycje miały według pruskich urzędników wzbudzać wśród Polaków pogardę wobec ludności niemieckiej $^{24}$. Jakie książki były konfiskowane i poddawane cenzurze dowiadujemy się z pism Królewskiego Sądu Krajowego (Königlichen Landgericht) w Chojnicach. Wynika z nich, że z polskich bibliotek ludowych w Wielkim Mędromierzu i Koślince poddano szczegółowej analizie następujące książki: Ukryte skarby Jana Kantego Gregorowicza (wyd. 1867); Jan III Sobieski król Polski i obrońca chrześcijaństwa. Powieść historyczna z czasów odsieczy Wiednia (wyd. 1883); $W$ domu najlepiej Serafina Jonasa (wyd. 1872) oraz Dzieje narodu polskiego dla ludu i młodzieży J. Chociszewskiego (wyd. 1883) ${ }^{25}$. Natomiast w bibliotece ludowej w Kiełpinie władze pruskie podejrzenia skierowały, m.in. na następujące książki: Życie i zastugi Jana III Sobieskiego pogromcy Turków Jana Piotrowina (wyd. 1877); Pamiętniki Jana Kilińskiego; Do Ameryki; Ofiara Żmudzina. Obrazek historyczny z czasów powstania 1831 roku, Z kujawskiej ziemi Chwalibora; Polacy w Danii czyli Wiekopomne czyny wojenne Stefana Czarnieckiego z roku 1658 i 1659 wedle pamiętników Paska i pamiętników Łosia opowiedziane (wyd. 1886) ${ }^{26}$.

Częste rewizje, konfiskata książek, które według władz zaborczych antagonizowały Polaków i Niemców, a nawet procesy sądowe osób prowadzących biblioteki nie zniechęcały polskich społeczników pracujących na rzecz rozbudzenia świadomości narodowej wśród ludu. Działalność TCL opierała się na bezinteresownej pracy jego członków, a książki były kupowane za bardzo niskie składki członkowskie oraz fundusze pochodzące ze zbiórek publicznych. Tworzeniem bibliotek zajmował się bibliotekarz główny z poznańskiej centrali organizacji, który na prośbę delegatów TCL wysyłał zbiory książek do lokalnych bibliotekarzy - z reguły byli nimi przedstawiciele miejscowej inteligencji. Niestety, księgozbiory na skutek niewystarczającego nadzoru bibliotekarzy (pracujących społecznie) oraz z powodu kontroli policyjnych, ulegały rozproszeniu lub zniszczeniu ${ }^{27}$. W pierwszych latach działalności TCL biblioteki ludowe były zakładane intuicyjnie, ale w zasadzie bazowały na wcześniejszych czytelniach ludowych lub parafialnych. Pomimo usilnych starań władz pruskich - konfiskat książek, karania polskich społeczników - nie udało się

24 Archiwum Państwowe w Bydgoszczy (dalej APB), Landratsamt Tuchel (dalej LA Tuchel), sygn. 41, k. 25-26, 101-169.

25 APB, LA Tuchel, sygn. 41, k. 59-72, 91.

26 APB, LA Tuchel, sygn. 41, k. 37, 179.

27 J. Kisielewski, dz. cyt., s. 288-289. 
wymazać z pamięci mieszkańców faktu istnienia w ich miejscowości polskiej biblioteki. Potwierdza to, że były one bardzo istotnym czynnikiem kulturotwórczym, silnie wzmacniającym świadomość narodową. Taką determinacją po raz kolejny wykazał się T. Krzeszewski, który pomimo wyroku sądowego i likwidacji śliwickiej czytelni ludowej w kwietniu 1880 r., a więc zanim powstało TCL w Poznaniu, ponownie zorganizował bibliotekę w Śliwicach, która następnie została włączona w struktury tej organizacji ${ }^{28}$. Dzięki podobnym działaniom w 1890 r. w powiecie tucholskim funkcjonowało dziesięć bibliotek, którymi kierowali miejscowi społecznicy. Działały one w Klonowie (Górski), Kielpinie (Franciszek Mięsikowski), Pamiętowie (Weltrowski), Wielkim Mędromierzu (Rolbiecki), Śliwicach (Jakub Szmagliński), Koślince (Cherek), Gostycynie (Antoni Borzyszkowski), Cekcynie (Talaśka, Zieliński), Bysławiu (Podlewski) i Raciążu (Kręcki) ${ }^{29}$.

W powiecie tucholskim organizacją oraz późniejszą koordynacją sieci bibliotecznej zajął się Kazimierz Karasiewicz. W 1888 r. po zakończeniu studiów medycznych i odbyciu praktyki lekarskiej przeprowadził się do stolicy Borów Tucholskich. Równocześnie z pracą zawodową zaangażował się w działalność narodową, oświatową i spółdzielczą. Syn burmistrza urodzony w wielkopolskim Słomowie swoje doświadczenia z Wielkopolski przeniósł na ziemię pomorską. $\mathrm{Z}$ jego inicjatywy powstało $\mathrm{w}$ Tucholi wiele organizacji społecznych, m.in. Towarzystwo Gimnastyczne „Sokół”, Towarzystwo Ludowe oraz Koło Śpiewackie. Był założycielem „Spółki Ziemskiej” oraz „Rolnika”, należał do zarządu tucholskiego Banku Ludowego. To właśnie w siedzibie tegoż banku wszystkie organizacje mogły prowadzić swoją działalność. W latach 1905-1908 Karasiewicz pełnił rolę delegata TCL na powiat tucholski, a w latach 1914-1918 był prezesem komitetu powiatowego tej organizacji ${ }^{30}$. W pracy aktywnie pomagali mu, m.in. córka Zofia oraz Klemens Rzendkowski

Na początku XX w. rozpoczął się proces reformowania struktur TCL, którego celem było usprawnienie jego organizacji wewnętrznej oraz dążenie do ulepszenia księgozbiorów bibliotecznych i modyfikacji sposobów ich udostępniania czytelnikom. Szybkie postępy w pracy oświatowej miała zapewnić nowa struktura terytorialna. Według założeń z 1909 r. nad rozwojem lokalnej sieci bibliotecznej miał czuwać komitet powiatowy, składający się z prezesa, sekretarza, bibliotekarza i skarbnika oraz członków, których liczba była równa ilości okręgów w danym powiecie. Okręgi miały być jak najmniejsze i obejmować od czterech do sześciu miejscowości, najlepiej z tej

A. Węsierski, dz. cyt., s. 70.

APB, LA Tuchel, sygn. 41, k. 204, 215, 217.

30 J. Podgóreczny, Niepospolici Ludzie Kujaw i Pomorza, Bydgoszcz 1967, s. 150; Wybitni, Niepospolici, Zastużeni. Znani i nieznani, czasem zapomniani przedstawiciele regionu, oprac. M. Ollick, Tuchola 2004, s. 83-84. 
samej parafii. Nie wymagano, aby obszar okręgów pokrywał się z granicami administracyjnymi poszczególnych gmin. Wraz ze zmianami organizacyjnymi kształtowały się podstawy technicznego funkcjonowania bibliotek. W powiecie bibliotekami opiekował się bibliotekarz powiatowy, którego głównym zadaniem było rozsyłanie książek do poszczególnych placówek. Warto w tym miejscu zaznaczyć, że książki, które można było wypożyczać, były kupowane przez poznańską centralę TCL, a następnie ich komplety rozsyłano do komitetów powiatowych ${ }^{31}$. Taki sposób zaopatrywania bibliotek nie wszystkim odpowiadał, ponieważ książki były niewłaściwie rozsyłane. Jak zauważył jeden z krytyków dotychczasowego systemu - w jednej bibliotece znajdowało się kilka tych samych egzemplarzy, do bibliotek dla dzieci trafiały książki dla dorosłych, a niektóre publikacje dla dorosłych były zbyt ambitne i dla nich niezrozumiałe ${ }^{32}$. Tym bardziej, że ze zbiorów bibliotecznych w mniejszych miastach i na wsiach korzystały głównie dzieci, a także robotnicy i gospodarze oraz czasami kupcy i rzemieślnicy. Ta ostatnia grupa $\mathrm{z}$ reguły miała do dyspozycji księgozbiory tematyczne zlokalizowane w siedzibach swoich towarzystw. Dlatego w TCL wprowadzono system wysyłania książek oparty na sześciu typach (spisach) bibliotek, który polegał na wymianie danego księgozbioru w momencie, gdy wyraźnie spadło nim zainteresowanie ze strony czytelników. Nad procesem wymiany książek miał czuwać bibliotekarz powiatowy. Do niego w czerwcu każdego roku biblioteki z terenu powiatu odsyłały dotychczasowy księgozbiór, który był sprawdzany pod względem ilościowym i jakościowym. Uszkodzone egzemplarze naprawiano, aby mogły być ponownie rozesłane we wrześniu. Ponadto bibliotekarz powiatowy był zobowiązany do zwoływania zebrań bibliotekarzy, podczas których zaznajamiał ich z zasadami ,prowadzenia bibliotek, obchodzenia się z książkami, sposobu wypożyczania"33. Dzięki temu co roku każda biblioteka otrzymywała nowe książki. O tym, ile nowych książek trafiło do powiatu tucholskiego z poznańskiej centrali, dowiadujemy się z corocznych sprawozdań statystycznych. W roku sprawozdawczym 1908/1909 przesłano z Poznania 186 nowych książek, a w kolejnym $306^{34}$. Rekordowo dużo - 389 egzemplarzy - trafiło do powiatu tucholskiego w roku sprawozdawczym 1910/191135. W następnych latach liczba ta stopniowo malała do 250 woluminów w 1912

${ }^{31}$ S. Rowiński, Praca organizacyjna w obrębie T.C.L. w Poznaniu, „Przegląd Oświatowy” 1910, z. 1, s. 3-6.

32 A. S., Wysytki książek z centralnego biura T.C.L., „Przegląd Oświatowy” 1910, z. 1, s. 17.

33 S. Rowiński, dz. cyt., s. 5.

34 Sprawozdanie Zarzadu Gtównego za czas od 1-go lipca 1909 do 1-go lipca 1910, „Przegląd Oświatowy" 1910, z. 11, s. 327.

35 Sprawozdanie Towarzystwa Czytelni Ludowych za czas od 1-go lipca 1910 do 1-go lipca 1911, „Przegląd Oświatowy” 1911, z. 11, s. 334. 
i $200 \mathrm{w}$ roku następnym ${ }^{36}$. Zaledwie 56 nowych książek przesłano w roku sprawozdawczym 1913/1914 ${ }^{37}$.

Bibliotekarze nie mieli być tylko „machiną do wypożyczania książek”38, mieli przenosić swoją działalność poza mury biblioteki i być agentami swojej instytucji. Dlatego członkowie TCL, obok upowszechniania słowa drukowanego, za pomocą książek i czasopism mieli podnosić poziom wiedzy okolicznych mieszkańców - zwłaszcza tych z niższych warstw społecznych, poprzez wykłady popularnonaukowe, spotkania czytelnicze, wieczornice i wiece ludowe ${ }^{39}$. Zgromadzenia te były doskonałą okazją do propagowania idei oświatowych organizacji.

Gdy na mocy rozporządzenia z 7 IX 1887 r. usunięto język polski ze szkół i urzędów to działacze TCL zaangażowali się w organizację wieców, na których wyrażano sprzeciw wobec działań pruskiej władzy. W Tucholi wiec odbył się 12 I 1888 r. Wystąpienia te były doskonałą okazją dla organizacji do pozyskania nowych członków, jak i zakładania nowych bibliotek. Po jednym z takich wieców w Śliwicach, który odbył się pod auspicjami TCL, powstały biblioteki w Osiecznej, Szlachcie, Legbądzie i Rzepicznej ${ }^{40}$.

Z kolei organizowane wykłady, często były urozmaicane pokazem zdjęć z różnych części Polski, Europy i świata wyświetlanych na ekranie projekcyjnym. W listopadzie i grudniu 1912 r. tucholski komitet powiatowy TCL zorganizował na terenie powiatu tucholskiego wiece oświatowe w Bysławiu, Cekcynie, Gostycynie i Wielkim Mędromierzu. Mieszkańcy tychże wsi, w szczególności młodzież, dzięki projektorowi mogli zobaczyć zdjęcia Warszawy, Krakowa i obrazów Matejki. Podczas tych spotkań K. Karasiewicz mówił o potrzebach oświaty, natomiast bibliotekarz powiatowy $-\mathrm{K}$. Rzendkowski o znaczeniu czytelni ludowych i ich organizacji ${ }^{41}$. Ze sprawozdania za rok 1912/1913 wynika, że na terenie powiatu odbyło się sześć wieców oświatowych oraz siedem odczytów lub wieczornic ${ }^{42}$.

K. Karasiewicz znany był w okolicy ze swych płomiennych przemówień i ogromnego zaangażowania w sprawy narodowe. W 1890 r. wraz z Majką z Tucholi wszedł w skład komitetu uroczystości pogrzebowej Adama Mickiewicza $^{43}$. W 1903 r. podczas wieczornicy upamiętniającej księdza Augustyna

\footnotetext{
36 Sprawozdanie Towarzystwa Czytelni Ludowych za czas od 1-go lipca 1912 do 1-go lipca 1913, „Przegląd Oświatowy” 1913, z. 11, s. 281.

37 Sprawozdanie Zarządu Głównego, „Przegląd Oświatowy” 1915, z. 1-2, s. 17.

Do bibliotekarzy, „Przegląd Oświatowy” 1912, z. 10, s. 252.

39 A. Ludwiczak, Praca organizacyjna, „Przegląd Oświatowy” 1912, z. 4, s. 102.

40 A. Węsierski, dz. cyt., s. 85.

Z powiatu tucholskiego, „Przegląd Oświatowy” 1913, z. 2, s. 39.

Tamże.

Komitet uroczystości pogrzebowej Mickiewicza, „Gazeta Toruńska” 1890, nr 139, s. 2.
} 
Kordeckiego wygłosił mowę na temat najazdu szwedzkiego w 1655 r. i zasług dowódcy obrony klasztoru na Jasnej Górze. Zachęcał również zgromadzonych do nauki historii ojczyzny ${ }^{44}$. Za swoją działalność określany był przez władze pruskie cichym agitatorem, a w spisie polskich przywódców (polnische Führer) z 1913 r. został wpisany na pierwszej pozycji, zaraz za nim znalazł się bibliotekarz powiatowy K. Rzendkowski ${ }^{45}$.

Pracę u podstaw, jaką TCL prowadziło w zaborze pruskim doskonale podsumowują słowa Augustiniego - specjalnego komisarza policji do spraw tej organizacji: „Bez wątpienia jest Towarzystwo Czytelni Ludowych wskutek swojej na zewnątrz niewinnie wyglądającej działalności organizacją najniebezpieczniejszą, a w polskiej agitacji najskuteczniejszą" ${ }^{46}$. Inny z komisarzy stwierdził:

Aczkolwiek Towarzystwo unikać usiłuje zagadnień bieżącej polityki i omija agitację pod względem partyjno-politycznym, to jednak stara się ze wszystkich sił szerokie masy entuzjazmować przeszłością narodową i wzbudzać tęsknotę za urzeczywistnieniem przyszłych planów narodowych ${ }^{47}$.

W roku poprzedzającym wybuch I wojny światowej dzięki staraniom wielu ludzi, biblioteka w Tucholi cieszyła się dużym zainteresowaniem, odnotowano znaczny wzrost czytelników, zwłaszcza wśród dzieci. Jedynym problemem, zjakim zmagał się tucholski komitet powiatowy TCL, była słaba ściągalność składek członkowskich, które były przeznaczane na zakup książek. Utrudnieniem była także bierność ze strony lokalnych proboszczów, którzy nie włączali się w akcje oświatowe i nie uczestniczyli w organizowanych wiecach ${ }^{48}$. W 1914 r. na terenie powiatu było 12 bibliotek posiadających w sumie 728 książek $^{49}$.

Wybuch wojny spowolnił dynamiczny rozwój TCL, ale działania wojenne nie doprowadziły do upadku idei szerzenia oświaty wśród ludu, która pośrednio przyczyniła się do odzyskania niepodległości przez Polskę cztery lata później.

Prezes organizacji ksiądz Antoni Ludwiczak apelował, aby wobec nadchodzących przemian, które niesie za sobą wojna, podtrzymywać pracę oświato$\mathrm{wąc}^{50}$. W $1917 \mathrm{r}$. Karasiewicz podczas wiecu w Bysławiu wygłosił mowę na temat zasług Tadeusza Kościuszki dla narodu polskiego oraz zachęcał, aby jego patriotyczna postawa była wzorem dla wszystkich Polaków ${ }^{51}$. W listopadzie

44 Tuchola, „Gazeta Toruńska” 1903, nr 293, s. [2].

45 APB, LA Tuchel, sygn. 44, Liste der polnischen Führer..., b.p.; J. Szwankowski, Powiat tucholski w latach 1875-1920. Administracja, ludność, gospodarka, kultura, Tuchola 2005, s. 250.

4655 lat pracy T.C.L. dla Polski..., s. 8.

47 Tamże.

48 Z powiatu tucholskiego..., s. 40.

49 Sprawozdanie Zarządu Głównego, „Przegląd Oświatowy” 1915, nr 1-2, s. 21.

5055 lat pracy T.C.L. dla Polski..., s. 7.

51 W Bysławiu, „Gazeta Toruńska” 1917, nr 288, s. [2]. 
1918 r. przez państwo pruskie przetoczyła się fala rewolucyjna i zaczęły tworzyć się Rady Robotnicze i Żołnierskie. Rozejm pokojowy podpisany pomiędzy państwami Ententy a Niemcami ożywił życie polityczne także w powiecie tucholskim. Od 22 do 25 listopada w całym powiecie odbyły się wybory członków do rad chłopskich (włościańskich). K. Karasiewicz otworzył wiec, który odbył się 24 listopada w Tucholi. Jak pisano w prasie, przedstawił on ,położenie polityczne, nasze żądania i prawo należenia do Polski" "52. O jego wielkiej mądrości świadczy fakt, że w swoim przemówieniu ,scharakteryzował dobrodziejstwa pruskie” i zachęcał „do zgody, spokoju i unikania jakiejkolwiek burdy" 53 . Podczas tucholskiego wiecu wybrano dwóch delegatów na polski Sejm Dzielnicowy, który na początku grudnia miał odbyć się w Poznaniu - byli nimi K. Karasiewicz i K. Rzendkowski. Obecni na tucholskim wiecu Polacy uchwalili także rezolucję, której pierwszy punkt dotyczył wprowadzenia nauki języka polskiego we wszystkich szkołach powszechnych na terenie powiatu i w miejscowym seminarium nauczycielskim oraz protestu ,przeciw napędzaniu dzieci polskich na niemieckie nabożeństwa tzw. szalmesy" i żądaniu mszy świętej z polskim śpiewem ${ }^{54}$. Liczne relacje prasowe potwierdzają, że kilkudziesięcioletnia praca u podstaw i uświadamianie narodowe nie poszły na marne. Osoby, które do tego się przyczyniły zyskały uznanie społeczne i cieszyły się dużym autorytetem, np. bibliotekarz powiatowy K. Rzendkowski w lutym 1920 r. został mianowany komisarycznym burmistrzem Tucholi ${ }^{55}$.

Wojsko polskie wkroczyło do powiatu tucholskiego, który znalazł się w granicach odrodzonej Polski, dopiero w ostatnich dniach stycznia 1920 r. Jednak działacze TCL dużo wcześniej powrócili do wypracowanych uprzednio sposobów działania. W kwietniu 1919 r. w „Pielgrzymie” informowano, że w powiecie tucholskim założono nowe biblioteki w:

Cekcynie u pani Marasz, w Gostyczynie u p. Władysława Czerwińskiego, w W. Mędromierzu u panny Kłosowskiej, w Raciążu u p. Franc. Gierszewskiego, w Pruszczu u p. Ignacego Zielińskiego, w Minikowie u p. Fr. Ostrowickiego, w Iwcu u p. Osowskiego, w Bysławiu u p. Józefa Kobierowskiego i w Kiełpinie u panny Glazy ${ }^{56}$.

Jednocześnie zachęcano mieszkańców powiatu do korzystania z oferty bibliotek. Tucholska placówka była otwarta jedną godzinę w niedziele i święta od godziny 12.00 , a w dni powszednie od $19.00^{57}$.

52 Tuchola, „Dziennik Bydgoski” 1918, nr 274, s. [3].

53 Tamże.

54 Tamże.

55 P. Redlarski, Klemens Rzendkowski, referat wygłoszony podczas lekcji historii regionalnej, która odbyła się 5 II 2016 r. w Miejskiej Bibliotece Publicznej w Tucholi, msp, w zbiorach Miejskiej Biblioteki Publicznej w Tucholi im. Aleksandra Janty-Połczyńskiego.

56 Tuchola, „Pielgrzym” 1919, nr 48, s. [2].

57 Tamże. 
W nowej sytuacji społeczno-politycznej charakter działalności polskich organizacji oświatowych z konieczności musiał ulec zmianie. Jak zaznaczył ksiądz A. Ludwiczak podczas II Zjazdu Oświatowego TCL na Pomorze, który odbył się 15 IX 1921 r. w Grudziądzu, na terenie, na którym „niewola pruska poczyniła wielkie szkody na podniesieniu oświaty ludu" 58 akcja oświatowa była szczególnie ważna. W pierwszym kwartale 1921 r. ksiądz Alojzy Karczyński odwiedził wszystkie pomorskie komitety powiatowe TCL. Jego zadaniem było ,uruchomienie czytelnictwa tam, gdzie ono zamarło, uzupełnienie istniejących już bibliotek oraz wskazanie komitetom nowych dróg i środków oświatowych"59. Jak dowiadujemy się ze sprawozdania A. Karczyńskiego, tucholski komitet powiatowy był ,jednym z najlepiej zorganizowanych pod względem czytelnictwa" ${ }^{60}$. W trakcie wizytacji A. Karczyńskiego odbyły się wiece w Bysławku, Klonowie, Raciążu, Pruszczu, Gostycynie i Cekcynie. W Tucholi wiec nie doszedł do skutku, ponieważ ze względu na okres karnawałowy wszystkie sale były zajęte ${ }^{61}$. Według sprawozdawcy, spośród 14 bibliotek w powiecie tucholskim najlepiej prosperowała ta w Tucholi, która miała osobną bibliotekę dla dzieci, dzięki czemu zaspokajała „głód duchowy najmłodszych czytelników" "22. Biblioteki organizowały kursy pisowni polskiej, a w rocznicę uchwalenia Konstytucji 3 Maja urządzono przedstawienie teatralne. Panująca drożyzna przyczyniła się do wzrostu liczby osób korzystających z bibliotek, gdyż mieszkańcy przestali prenumerować gazety ${ }^{63}$.

Działalność TCL podczas zaborów zyskała uznanie w niepodległej Polsce. Obchody jednego z najważniejszych świąt narodowych połączono ze zbiórką datków na tzw. „Dar Narodowy Trzeciego Maja Towarzystwa Czytelni Ludowych”. W ten sposób doceniono to, że Towarzystwo „przez dziesiątki lat oświecało i wychowywało najszersze warstwy ludowe" ${ }^{64}$. Zebrane w ten sposób środki nadal miały być przeznaczane na cele oświatowe, gdyż odradzające się państwo potrzebowało ,światłych głów i tęgich charakterów" ${ }^{65}$. $\mathrm{Z}$ dzisiejszego punktu widzenia było to doskonałe posunięcie marketingowe. TCL zyskało bowiem dodatkowe źródło finansowania oraz miało okazję do podkreślenia swych zasług w zakresie szerzenia oświaty wśród ludu i kształtowania propolskich postaw w okresie zaborów. Corocznie, przed 3 maja

58 Drugi Zjazd Oświatowy Towarzystwa Czytelni Ludowych na Pomorze, „Przegląd Oświatowy" lipiec-wrzesień 1921, s. 43.

59 APB, Towarzystwo Czytelni Ludowych w Grudziądzu (dalej TCL w Grudziądzu), sygn. 14, k. 17.

60 Tamże, k. 18.

61 Tamże, k. 18.

62 Tamże, k. 21.

63 Tamże, k. 21.

${ }^{64}$ APB, TCL w Grudziądzu, sygn. 43, k. 319.

65 Tamże. 
w artykułach prasowych przypominano, jak wielką wartością dla utrzymania polskiej niepodległości i pomyślnego rozwoju kraju jest wykształcenie szerokich warstw społeczeństwa. W jednym z tekstów, który ukazał się w „Dniu Grudziądzkim” tak uzasadniano dlaczego rocznica Konstytucji 3 Maja jest dniem zbiórki na cele oświatowe:

W dziejach Polski konstytucja i oświata są i powinny być ściśle ze sobą złączone: jak z jednej strony z oświaty i przez oświatę powstała konstytucja, tak z drugiej ta ostatnia nie może istnieć bez pierwszej. [...] istnieje jeszcze druga zależność: nie tylko tworzenie konstytucji wymaga wiedzy i oświaty, niemniej wymaga ich samo istnienie konstytucji, czyli umiejętności korzystania z jej praw: analfabeta lub półanalfabeta nigdy nie będzie umiał korzystać z dobrodziejstw konstytucji ${ }^{6}$.

Tylko 1/4 środków pozyskanych w drodze publicznej zbiórki pozostawała w komitetach powiatowych, reszta trafiała do centrali TCL w Poznaniu i była przeznaczana na zakup książek. W 1921 r. tucholski komitet powiatowy zebrał 24182 marek. Ponad 17000 odesłano do Poznania, pozostałe środki przeznaczono na powiększenie liczby bibliotek w powiecie. Natomiast w dniu 3 V 1926 r. na Dar Narodowy tucholski komitet TCL zebrał 215,60 zł.

W latach 20. i 30. XX w. liczba bibliotek TCL w powiecie tucholskim utrzymywała się na podobnym poziomie. Od $1926 \mathrm{r}$. funkcję prezesa komitetu powiatowego organizacji pełniła Zofia Preis z domu Karasiewicz. W 1928 r. biblioteki funkcjonowały w: Tucholi (bibliotekarze Zofia Lipska, Zofia Preis), Jeleńczu (M. Kallassowa), Bysławiu (J. Kobierowski), Raciążu (Józef Szews), Klonowie (Jan Szczech), Minikowie (Paweł Berent), Wielkim Mędromierzu (M. Kłosowska), Kiełpinie (Mięsikowska), Gostycynie (Ogrzewalski), Wielkiej Kloni (Kruppin), Rzepicznej (Megger), Cekcyn (Nagórski), Bralewnica (Ossowska), Biała (Glinka), Stary Sumin (Kilichowski), Śliwice (Władysław Landowski). Skorzystało z nich w tym roku 634 czytelników, którzy wypożyczyli 8882 książki $^{67}$. Działalność placówek nadal skupiała się na podnoszeniu wykształcenia obywateli poprzez rozwijanie czytelnictwa, a także urządzanie obchodów i wieczornic tematycznych. Ważne wydarzenie miało miejsce w 1933 r., w którym na przełomie listopada i grudnia obchodzono Tydzień Książki Polskiej. Jego celem było propagowanie książek wśród najszerszych warstw społeczeństwa, aby nastąpił wzrost czytelnictwa. Z tej okazji w tucholskiej bibliotece została urządzona wystawa książki polskiej ${ }^{68}$.

Podsumowując można stwierdzić, że założone w 1880 r. TCL wywarło ogromny wpływ na kształtowanie świadomości narodowej Polaków żyjących w zaborze pruskim. Z powodzeniem kontynuowało starania zapoczątkowane

66 APB, TCL w Grudziądzu, sygn. 37, k. 81.

${ }^{67}$ APB, TCL w Grudziądzu, sygn. 31, k. 127.

68 T.C.L. Tuchola, „Głos Tucholski” 1933, nr 139, s. 4. 
przez Ligę Polską. Działalność organizacji oświatowej, jaką było Towarzystwo, przypadła na lata wzmożonej germanizacji. W tych trudnych dla Polaków czasach było ono ostoją polskości. Gdy zamykano polskie szkoły katolickie, likwidowano seminaria duchowne, usuwano język polski ze szkół, urzędów, sądów, to biblioteki ludowe były podporą polskiej tożsamości. Sieć biblioteczna tworzona na terenach zaboru pruskiego w pełni i z powodzeniem realizowała cel, jaki postawiło przed sobą TCL. Poprzez propagowanie książek i czytelnictwa nie pozwolono zapomnieć o języku narodowym i polskiej historii. Było to szczególnie ważne w chwili odzyskiwania przez Polskę niepodległości. Nie wiemy, jaki los spotkałby Pomorze Nadwiślańskie, gdyby nie lata pracy u podstaw wielu polskich społeczników. Doświadczenia z okresu zaborów z powodzeniem wykorzystano w odrodzonej Polsce. Charakter działania musiał się zmienić, chociaż nadal istotny był rozwój czytelnictwa. W nowej rzeczywistości społeczno-politycznej TCL-z powodzeniem - czuwało

nad podnoszeniem społeczeństwa na coraz wyższy stopień kultury duchowej, [...] nad wychowaniem każdego Polaka na obywatela chętnego do pracy państwowotwórczej, na obywatela owianego gorąca miłością Ojczyzny [...] nad szerzeniem oświaty i dokładało wszelkich starań, aby tego dokonać ${ }^{69}$.

\section{Bibliografia}

Archiwum Państwowe w Bydgoszczy, zespół Landratsamt Tuchel, sygn. 41.

Archiwum Państwowe w Bydgoszczy, zespół Towarzystwo Czytelni Ludowych w Grudziądzu, sygn. 14, 31, 37, 43.

55 lat pracy T.C.L. dla Polski 1880-1935. Rzut oka na historię Towarzystwa Czytelni Ludowych, Poznań 1935.

A.S., Wysytki ksiażek z centralnego biura T.C.L., „Przegląd Oświatowy” 1910, z. 1, s. 17-19. Do bibliotekarzy, „Przegląd Oświatowy” 1912, z. 10, s. 252-256.

Drugi Zjazd Oświatowy Towarzystwa Czytelni Ludowych na Pomorze, „Przegląd Oświatowy" lipiec-wrzesień 1921, s. 43-47.

Jakóbczyk W., Cieszkowski i Liga Polska, „Przegląd Historyczny” 1948, t. 38, s. 137-168. Kisielewski J., Bibliotekarstwo powszechne na zachodnich ziemiach Polski. Z okazji 50-lecia pracy Towarzystwa Czytelni Ludowych 1880-1930, „Przegląd Biblioteczny” 1930, z. 3, s. 281-303.

Komitet uroczystości pogrzebowej Mickiewicza, „Gazeta Toruńska” 1890, nr 139, s. 2.

Krzemiński T., Codzienność mniejszych miast Pomorza Nadwiślańskiego końca XIX i pierwszych dziesięcioleci XX wieku. Zmiany warunków materialnych i przeobrażenia obyczajowości, Warszawa 2017.

Lisiecki A., Czterdziestolecie T.C.L., „Przegląd Oświatowy” grudzień 1921, s. 85-89.

69 APB, TCL w Grudziądzu, sygn. 10, k. 90. 
Ludwiczak A., Praca organizacyjna, „Przegląd Oświatowy” 1912, z. 4, s. 102-106.

Mańkowski A., Czytelnictwo i bibliotekarstwo polskie na Pomorzu 1849-1889, „Mestwin” 1930, nr 15, s. 1-4.

Palędzki J., Ś.p. Józef Janta-Połczyński, „Gazeta Toruńska” 1890, nr 23, s. 2-3.

Podgóreczny J., Niepospolici Ludzie Kujaw i Pomorza, Bydgoszcz 1967, s. 150.

Pogrzeb ś.p. Józefa Połczyńskiego, „Gazeta Toruńska” 1890, nr 25, s. 4.

Rowiński S., Praca organizacyjna w obrębie T.C.L. w Poznaniu, „Przegląd Oświatowy” 1910, z. 1, s. 1-7.

Sprawozdanie Towarzystwa Czytelni Ludowych za czas od 1-go lipca 1910 do 1-go lipca 1911, „Przegląd Oświatowy” 1911, z. 11, s. 315-343.

Sprawozdanie Towarzystwa Czytelni Ludowych za czas od 1-go lipca 1912 do 1-go lipca 1913, „Przegląd Oświatowy” 1913, z. 11, s. 251-291.

Sprawozdanie Zarządu Głównego, „Przegląd Oświatowy” 1915, z. 1-2, s. 5-40.

Sprawozdanie Zarządu Głównego za czas od 1-go lipca 1909 do 1-go lipca 1910, „Przegląd Oświatowy" 1910, z. 11, s. 323-345.

Szwankowski J., Powiat tucholski w latach 1875-1920. Administracja, ludność, gospodarka, kultura, Tuchola 2005.

Ś.p. Józef Janta-Połczyński, „Dziennik Poznański” 1890, nr 27, s. [4].

T.C.L. Tuchola, „Głos Tucholski” 1933, nr 139, s. 4.

Tuchola, „Dziennik Bydgoski” 1918, nr 274, s. [3].

Tuchola, „Gazeta Toruńska” 1903, nr 293, s. [2].

Tuchola, „Pielgrzym” 1919, nr 48, s. [2].

Tuchola. Od pradziejów do współczesności. Praca zbiorowa, pod red. W. Jastrzębskiego, J. Szwankowskiego, Bydgoszcz-Tuchola 2010.

W Bysławiu, „Gazeta Toruńska” 1917, nr 288, s. [2].

Węsierski A., Dzieje parafii św. Katarzyny w Śliwicach w czasach zaboru pruskiego (1870-1920), Śliwice 2009.

Wróblewski J., Polskie biblioteki ludowe w zaborze pruskim i na terenie Rzeszy Niemieckiej w latach 1843-1939, Olsztyn 1975.

Wybitni, Niepospolici, Zastużeni. Znani i nieznani, czasem zapomniani przedstawiciele regionu, oprac. M. Ollick, Tuchola 2004, s. 83-84.

Z powiatu tucholskiego, „Przegląd Oświatowy” 1913, z. 2, s. 39-40. 
